\title{
FAST FARADAIC PROCESSES OBSERVED DURING THE POTENTIODYNAMIC POLARIZATION OF POLYCRYSTALLINE PALLADIUM IN ACID ELECTROLYTE
}

\author{
A.E. BOLZÁN, A.C. CHIALVO and A.J. ARVIA \\ Instituto de Investigaciones Fisicoquimicas Téricas y Aplicadas, Casilla de Correo 16, Sucursal 4, \\ 1900 La Plata (Argentina)
}

(Received 19th March 1984; in revised form 21st June 1984)

\section{ABSTRACT}

Two almost reversible electrochemical systems are detected during the potentiodynamic anodization of polycrystalline palladium in $1 \mathrm{M} \mathrm{H}_{2} \mathrm{SO}_{4}$ and $1 \mathrm{M} \mathrm{HClO}_{4}$ by applying the triangular modulated triangular potential sweep technique. The first electrochemical system which appears in the $0.7-0.9 \mathrm{~V}$ range (vs. RHE) corresponds to the reaction $\mathrm{Pd}+\mathrm{H}_{2} \mathrm{O}=\mathrm{PdOH}+\mathrm{H}^{+}+e^{-}$whose reversible potential is estimated as $0.80 \pm 0.02 \mathrm{~V}$ and the average half-life time of $\mathrm{PdOH}$ species is estimated as $6 \times 10^{-3} \mathrm{~s}$.

The second electrochemical system appears when the anodizing potential sweep extends to the oxygen evolution potential region. The appearance of the second electrochemical system is accompanied by a change in colour of the electrode surface, a shift of the current-potential curve of the oxygen evolution reaction and an increase in thickness of the oxide anodic layer. The reversible response is tentatively assigned to the $\mathrm{PdO}_{2} / \mathrm{PdO}_{3}$ redox couple.

\section{INTRODUCTION}

In recent years the application of triangularly modulated either linear (TMLPS) or triangular (TMTPS) potential sweep technique was found to be very useful for the detection and estimation of the degree of reversibility of the different individual stages of an electrochemical reaction $[1,2]$. This technique through the systematic adjustment of the perturbation conditions is in some cases suitable for separating the stages of a complex electrochemical reaction and gaining information about the half life time of reaction intermediates participating in faradaic processes [1-4]. Most of the data reported in the literature about the application of the TMPS technique refers to the electrosorption of $\mathrm{O}$ - and $\mathrm{H}$-adatoms on noble metals in the monolayer range, although it has also been applied to investigating the early stages of the corrosion and passivation of the iron group metals [5] and to the adsorption and electrooxidation of carbon monoxide on polycrystalline platinum $[6,7]$.

This work deals with the application of the TMPS technique to polycrystalline palladium electrodes in acid to investigate the characteristics of the initial charge transfer step related to $\mathrm{O}$-electroadsorption and of the different stages involved in 
the potential range of the anodic oxide layer electroformation including the oxygen evolution reaction potential region.

\section{EXPERIMENTAL}

Polycrystalline palladium working electrodes were made from a palladium wire (Johnson Matthey Chem. Co., spec. pure; $0.1 \mathrm{~cm}$ dia., $0.16 \mathrm{~cm}^{2}$ apparent area) mounted on a PTFE holder. Before each run the electrode was electropolished in 0.5 $M$ lithium chloride + methanol solution [8], rinsed with double distilled water, immersed for $10 \mathrm{~min}$ in concentrated sulphuric acid, and rinsed with thrice distilled water. After immersing the electrode in the electrolysis cell solution (either $1 \mathrm{M}$ $\mathrm{H}_{2} \mathrm{SO}_{4}$ or $1 \mathrm{M} \mathrm{HClO}_{4}$ ) it was subjected to a triangular potential cycling at $2 \mathrm{~V} \mathrm{~s}^{-1}$ within the $0.3-1.55 \mathrm{~V}$ range until a stabilized voltammogram was obtained. A palladium ancillary electrode and a hydrogen reversible reference electrode in either $1 \mathrm{M} \mathrm{H}_{2} \mathrm{SO}_{4}$ or $1 \mathrm{M} \mathrm{HClO}_{4}$ were used. Potentials in the text are referred to the RHE scale. The electrolyte was prepared from either $98 \%$ (Merck p.a.) sulphuric acid or $70 \%$ (Merck p.a.) perchloric acid and thrice distilled water which satisfied the usually accepted purity criteria [9]. Runs were made at $25^{\circ} \mathrm{C}$ in a purified nitrogen gas atmosphere. The perturbation signals applied to the working electrode were obtained from GRM3 LYP function generator coupled to a fast rise time $(\tau<5 \mu \mathrm{s})$ LYP M5 potentiostat and a Tektronik oscilloscope (type 536). The guide triangular potential sweep was applied at the potential sweep rate $v_{\mathrm{g}}\left(0.1 \leqslant v_{\mathrm{g}} \leqslant 2 \mathrm{~V} \mathrm{~s}^{-1}\right)$ between the switching potentials $E_{\mathrm{s}, \mathrm{c}}=0.3 \mathrm{~V}$ and $E_{\mathrm{s}, \mathrm{a}}\left(1.55 \leqslant E_{\mathrm{s}, \mathrm{a}} \leqslant 2.3 \mathrm{~V}\right)$. The modulated triangular potential sweep covered the amplitude $A_{\mathrm{m}}\left(20 \leqslant A_{\mathrm{m}} \leqslant 100 \mathrm{mV}\right)$ at the potential sweep rate $v_{\mathrm{m}}\left(5 \leqslant v_{\mathrm{m}} \leqslant 100 \mathrm{~V} \mathrm{~s}^{-1}\right)$. For the sake of comparison conventional repetitive triangular potential sweep (RTPS) voltammograms at the potential sweep $v=v_{\mathrm{g}}$ were also recorded.

\section{RESULTS}

Voltammetric runs covering up to $E_{s, a}=1.55 \mathrm{~V}$

There is a good correspondence between the RTPS voltammogram run at $2 \mathrm{~V} \mathrm{~s}^{-1}$ and the voltammograms run under a TMTPS from $E_{\mathrm{s}, \mathrm{c}}=0.3 \mathrm{~V}$ to $1.55 \mathrm{~V}$ at $v_{\mathrm{g}}=2 \mathrm{~V}$ $\mathrm{s}^{-1}, v_{\mathrm{m}}=10 \mathrm{~V} \mathrm{~s}^{-1}$ and $A_{\mathrm{m}}=50 \mathrm{mV}$ (Fig. 1). For the latter the positive potential scan exhibits an anodic current envelope with a net peak at $0.82 \mathrm{~V}$ (peak I(a)) and a complementary cathodic current envelope defining a peak (peak I(c)) at $0.76 \mathrm{~V}$ (first electrochemical system). The peak potential difference, $\Delta E_{\mathrm{p}}$, between peaks I(a) and $\mathrm{I}(\mathrm{c})$ is close to $60 \mathrm{mV}$. In the 1.0-1.2 V range a relatively large anodic current which continuously increases beyond $1.2 \mathrm{~V}$ is observed. In this potential range no cathodic current is recorded. The potential range of the conjugated current peaks $I(a)$ and $I(c)$ is related to underpotential discharge of water on palladium in acid electrolyte yielding adsorbed $\mathrm{OH}$ on the metal [10-12]. 
It should be noticed, however, that under the perturbation conditions indicated in Fig. 1, the charge $\left(Q_{\mathrm{a}}^{\mathrm{I}}\right)$ associated with peak $\mathrm{I}(\mathrm{a})$ is greater than that of peak $\mathrm{I}(\mathrm{c})$, $\left(Q_{\mathrm{c}}^{\mathrm{I}}\right)$. The systematic change of the perturbation parameters under a constant $A_{\mathrm{m}}$ and switching potential values shows that the $Q_{\mathrm{a}}^{\mathrm{l}} / Q_{\mathrm{c}}^{\mathrm{l}}$ ratio depends on the frequency, $f$, of the modulating signal, approaching two limiting values either $Q_{\mathrm{a}}^{\mathrm{I}} / Q_{\mathrm{c}}^{\mathrm{I}} \rightarrow \infty$ as $f \rightarrow 0$ or $Q_{\mathrm{a}}^{\mathrm{I}} / Q_{\mathrm{c}}^{\mathrm{l}} \rightarrow 1$ as $f \rightarrow \infty$ (Fig. 2). The detailed structure of the positive potential going voltammogram in relation to each cycle of the modulating signal (Fig. 3) shows a break in the corresponding $E-I$ profile which indicates the occurrence of two successive anodic reactions. Tentatively, the points in the $E-I$ plane where the change in the slope of the $E-I$ profile of each modulating sweep is observed, can be used as a criterion for evaluating the anodic charges $Q_{\mathrm{a}}^{\mathbf{I}_{1}}$ and $Q_{\mathrm{a}}^{\mathbf{I}_{2}}$ of

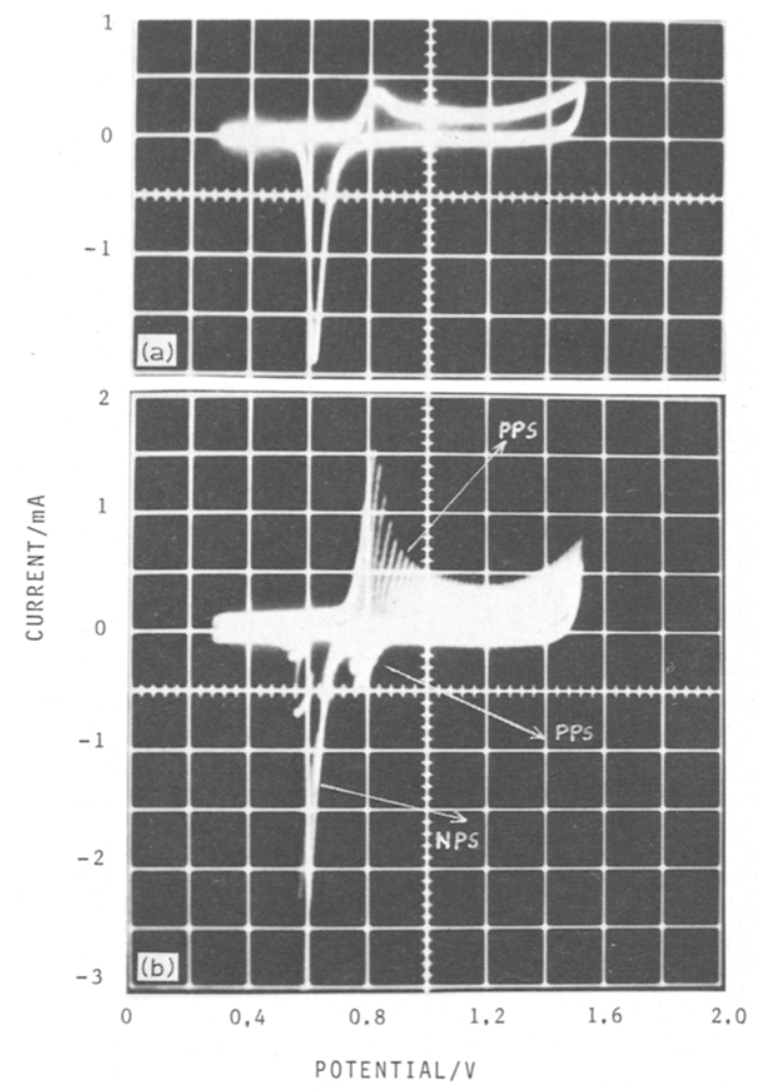

Fig. 1. (a) Repetitive triangular potential sweep (RTPS) stabilized voltammogram run at $2 \mathrm{~V} \mathrm{~s}^{-1} ; 1 M^{-1}$ $\mathrm{H}_{2} \mathrm{SO}_{4}$. (b) TMTPS E-I profile; $v_{\mathrm{g}}=2 \mathrm{~V} \mathrm{~s}^{-1}, v_{\mathrm{m}}=10 \mathrm{~V} \mathrm{~s}^{-1}, A_{\mathrm{m}}=50 \mathrm{mV} ; 1 \mathrm{M} \mathrm{H}_{2} \mathrm{SO}_{4}$. PPS; positive potential scan. NPS; negative potential scan. 


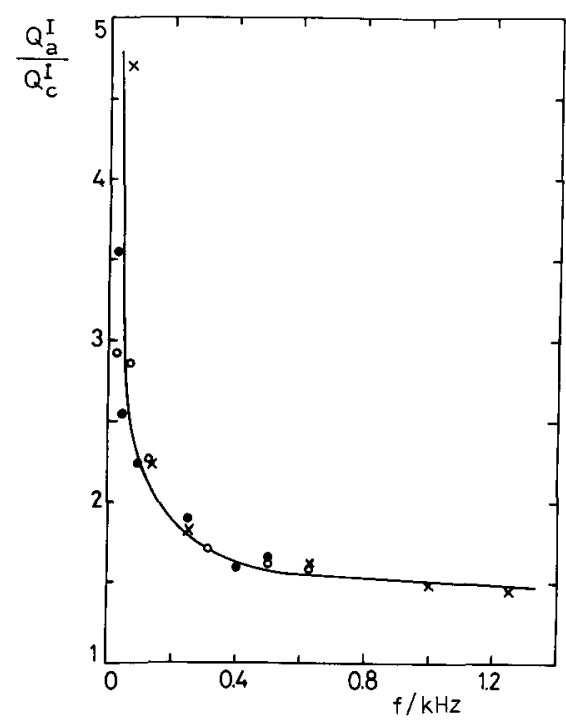

Fig. 2. Dependence of the $Q_{\mathrm{a}} / Q_{\mathrm{c}}$ ratio on the frequency of the modulating signal $\left(f=v_{\mathrm{m}} / A_{\mathrm{m}}\right) .(\times)$; $\mathrm{A}_{\mathrm{m}}=40 \mathrm{mV},(\mathrm{O}) ; A_{\mathrm{m}}=80 \mathrm{mV},(\bullet) ; A_{\mathrm{m}}=100 \mathrm{mV}$.

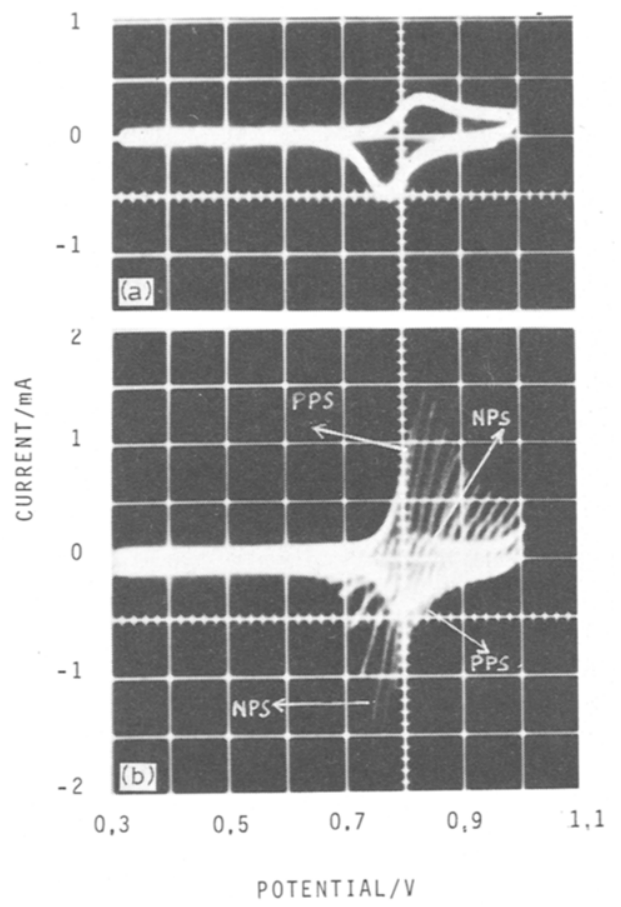

Fig. 3. (a) RTPS stabilized voltammogram run at $2 \mathrm{~V} \mathrm{~s}^{-1} ; 1 \mathrm{M} \mathrm{H}_{2} \mathrm{SO}_{4}$. (b) TMTPS E-I profile; $v_{\mathrm{g}}=2 \mathrm{~V}$ $\mathrm{s}^{-1}, v_{\mathrm{m}}=10 \mathrm{~V} \mathrm{~s}^{-1}, A_{\mathrm{m}}=50 \mathrm{mV} ; 1 \mathrm{M} \mathrm{H}_{2} \mathrm{SO}_{4}$. 
each anodic reaction on the basis that:

$Q_{\mathrm{a}}^{\mathrm{I}}=Q_{\mathrm{a}}^{I_{1}}+Q_{\mathrm{a}}^{\mathrm{I}_{2}}$

Independently of the parameters of the modulating signal, the $Q_{\mathrm{a}}^{\mathrm{I}} / Q_{\mathrm{c}}^{\mathrm{I}}$ charge ratio remains always practically equal to one.

The $E-I$ envelope recorded in the negative potential going direction starting from $E_{\text {s,a }}<1.55 \mathrm{~V}$, exhibits the characteristics of an irreversible electrochemical process [2] (Figs. 1(b) and 3(b)). Nevertheless, when $E_{\mathrm{s}, \mathrm{a}}<1.0 \mathrm{~V}$, a slight anodic current contribution which gradually increases as $E_{\text {s.a }}$ decreases downwards from $1.0 \mathrm{~V}$ is recorded. The latter extends over the potential range where detectable amounts of $\mathrm{OH}$ adsorbed species are produced (Fig. 1(b)).

Voltammetric runs covering from $E_{s, a}=1.8 \mathrm{~V}$ to $E_{s, a}=2.3 \mathrm{~V}$

In these experiments the $E_{\mathrm{s}, \mathrm{a}}$ value of the base signal extends beyond the potential range usually assigned to the formation of an O-electroadsorbed monolayer. The conventional RTPS voltammogram run from $0.3 \mathrm{~V}$ up to $2.3 \mathrm{~V}$ at $1 \mathrm{Vs}^{-1}$ (Fig. 4(a)) as compared to that shown in Fig. 1(a), exhibits during the negative potential going scan a new cathodic current contribution at ca. $1.4 \mathrm{~V}$ and a remarkable hysteresis between the positive and the negative potential going scans in the 1.4-2.0 V range.

The TMTPS run in the positive potential going direction shows another anodic-cathodic current envelope resembling that of a fast faradaic process (Fig. 4(b)). This second electrochemical system is considerably enhanced during the negative potential going scan and extends in the 1.2-1.8 $\mathrm{V}$ range and the corresponding anodic $\left(Q_{\mathrm{a}}^{\mathrm{II}}\right)$ and cathodic $\left(Q_{\mathrm{c}}^{\mathrm{II}}\right)$ charges are about twice the charge of peaks I(a) and I(c). It seems likely that the reversible processess undergone in the $1.2-1.8 \mathrm{~V}$ range and the oxygen evolution reaction (OER) occurring from $1.6 \mathrm{~V}$ upwards are mutually influenced, as it is suggested by the net polarization increase of the OER in going from the positive to the negative going potential scan. In any case, the corresponding charge ratio $\left(Q_{\mathrm{a}}^{\mathrm{II}} / Q_{\mathrm{c}}^{\mathrm{II}}\right)$ gives results equal to one, although the overall charge in the $1.2-1.8 \mathrm{~V}$ range increases accordingly to $E_{\mathrm{s}, \mathrm{a}}$ up to a limiting value. This effect should be attributed to the growth in thickness of the oxide layer taking place in the OER potential range. The second electrochemical system in the TMTPS voltammogram appears in the same potential range, where a plateau is observed during the open circuit potential decay of a palladium electrode anodized at potentials greater than $1.8 \mathrm{~V}$ (Fig. 5). Furthermore, in this case, after polarization the electrode at ca. $2 \mathrm{~V}$ it is covered with an anodic film exhibiting a golden hue. At higher positive potentials the colour of the anodic film changes to black.

To investigate this aspect of the reaction, the electrode was held at $2.0 \mathrm{~V}$ for $5 \mathrm{~min}$ before running the TMLPS at different $v_{\mathrm{g}} / v_{\mathrm{m}}$ ratios from $E_{\mathrm{s}, \mathrm{a}}$ downwards at different values of $v_{\mathrm{g}}, v_{\mathrm{m}}$ and $A_{\mathrm{m}}$ (Fig. 6). In this case a large electroreduction charge is observed in the $1.0-1.8 \mathrm{~V}$ range where apparently at least three different components, namely, the most reversible one at ca. $1.6 \mathrm{~V}$ which resembles that 
shown in Fig. 4, and another two more irreversible processes at ca. 1.1 and $1.3 \mathrm{~V}$, respectively (Figs. $6(\mathrm{~b})$ and $6(\mathrm{c})$ ) can be distinguished. However, the characteristics of the TMLPS voltammogram (Fig. 6(d)) become more reversible as $v_{\mathrm{g}}$ decreases and $v_{\mathrm{m}}$ increase (Figs. 6(b), (c) and (d)). Thus, at $v_{\mathrm{m}}=100 \mathrm{Vs}^{-1}$ fast faradaic processes are only detected through the TMLPS voltammogram (Fig. 6(d)). The resulting $E-I$ profiles for each modulating cycle at $v_{\mathrm{m}}=5 \mathrm{Vs}^{-1}$ along the 1.7-1.1 $\mathrm{V}$ range exhibit at least two linear portions which indicate different reaction resistances in the 1.7-1.1 V range (Fig. 7). The latter can be associated with the various stages involved in the electroreduction of the oxide layer which was built up at a constant potential in the oxygen evolution potential range.

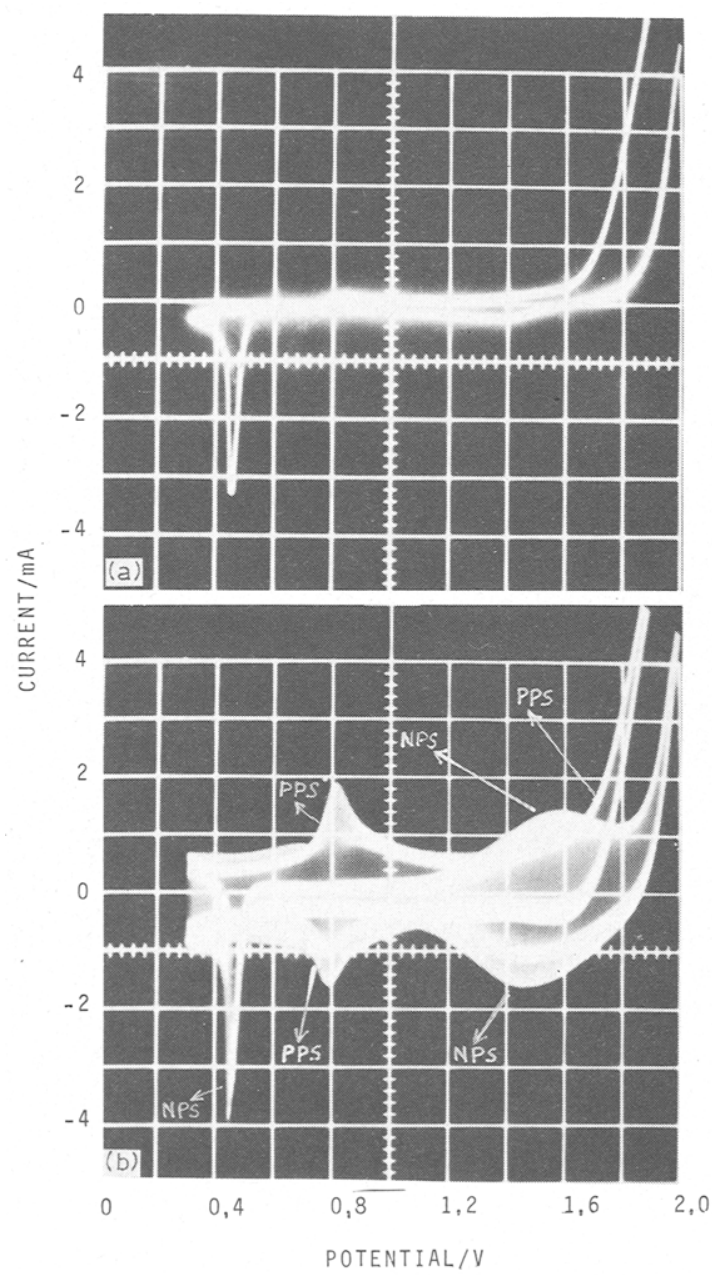

Fig. 4. (a) RTPS stabilized voltammogram run at $1 \mathrm{~V} \mathrm{~s}^{-1} ; 1 \mathrm{M} \mathrm{H}_{2} \mathrm{SO}_{4}$. (b) TMTPS E-I profile; $v_{\mathrm{g}}=1 \mathrm{~V}$ $\mathrm{s}^{-1}, v_{\mathrm{m}}=100 \mathrm{Vs}^{-1}, A_{\mathrm{m}}=20 \mathrm{mV} ; 1 \mathrm{M} \mathrm{H}_{2} \mathrm{SO}_{4}$. 
When the electrolyte is changed from $1 \mathrm{M} \mathrm{H}_{2} \mathrm{SO}_{4}$ to $1 M \mathrm{HClO}_{4}$, TMLPS voltammograms run with the latter under comparable conditions show an enhancement of the reversibility of the second electrochemical system occurring in the range $1.50-1.60 \mathrm{~V}$ (compare Figs. 6(b) and 6(c) to Figs. 8(a) and 8(b), respectively). Under the same experimental conditions the charge involved in $1 \mathrm{M} \mathrm{HClO}_{4}$ is considerably greater than that found in $1 \mathrm{M} \mathrm{H}_{2} \mathrm{SO}_{4}$.

\section{DISCUSSION}

The TMPS voltammograms detect two almost reversible electrochemical processes when polycrystalline palladium is polarized in acid electrolyte. One of these processes is observed during anodization in the $0.7-0.9 \mathrm{~V}$ range, while another one is found during cathodization from a potential greater than $1.8 \mathrm{~V}$ when an oxide layer was anodically formed on palladium.

The fast surface electrochemical reaction observed in the 0.7-0.9 $\mathrm{V}$ range corresponds to the initial stages of the O-electroadsorption on polycrystalline palladium in acid [10-12] as represented by the following reversible reaction (first electrochemical system)

$\mathrm{Pd}(\mathrm{s})+\mathrm{H}_{2} \mathrm{O}=\mathrm{Pd}(\mathrm{OH})+\mathrm{H}^{+}+e$

which corresponds to the underpotential discharge of water yielding the adsorbed $\mathrm{OH}$ radical. The equilibrium potential $\left(E_{1}^{\circ}\right)$ of reaction (2) estimated from the TMLPS voltammograms is $0.80 \pm 0.02 \mathrm{~V}$.

The potentiodynamic behaviour of the early stages of O-electroadsorption on palladium in acid results similar to that of other noble metals in different acid electrolytes [3,4,13]. Each modulation cycle of the TMTPS voltammogram run in the positive potential going direction exhibits the characteristics expected for the contribution of two consecutive electron transfer steps, with its proper reaction resistance $(\Delta E / \Delta I)$ and equilibrium potential $\left(E_{1}^{\circ}\right.$ and $\left.E_{2}^{\circ}\right)$, where $E_{2}^{\circ}-E_{1}^{\circ}<0$ [2]. Thus, step

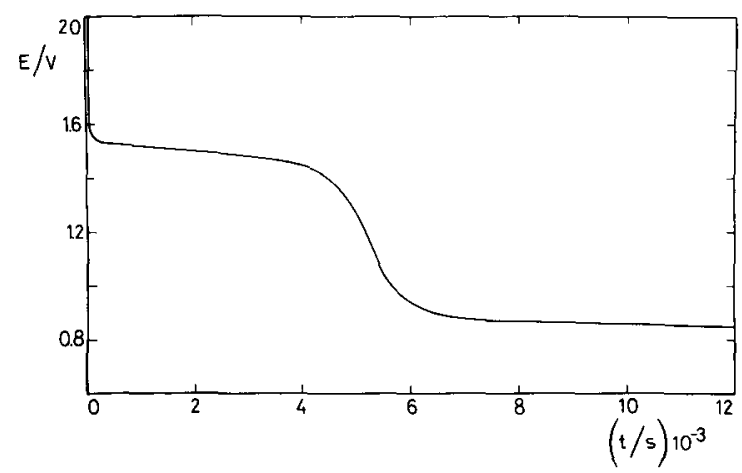

Fig. 5. Open circuit potential decay after anodizing at $E_{\mathrm{s}, \mathrm{a}}=2 \mathrm{~V}$ for $5 \mathrm{~min} ; 1 \mathrm{MH}_{2} \mathrm{SO}_{4}$. 
(3) is followed by the irreversible deprotonation of $\mathrm{Pd}(\mathrm{OH})$ yielding unstable $\mathrm{Pd}(0)^{*}$ according to

$\mathrm{Pd}(\mathrm{OH}) \rightarrow \operatorname{Pd}(\mathrm{O})^{*}+\mathrm{H}^{+}+e^{-}$

whose corresponding equilibrium potential $\left(E_{2}^{\circ}\right)$ should be more negative than $E_{1}^{\circ}$.

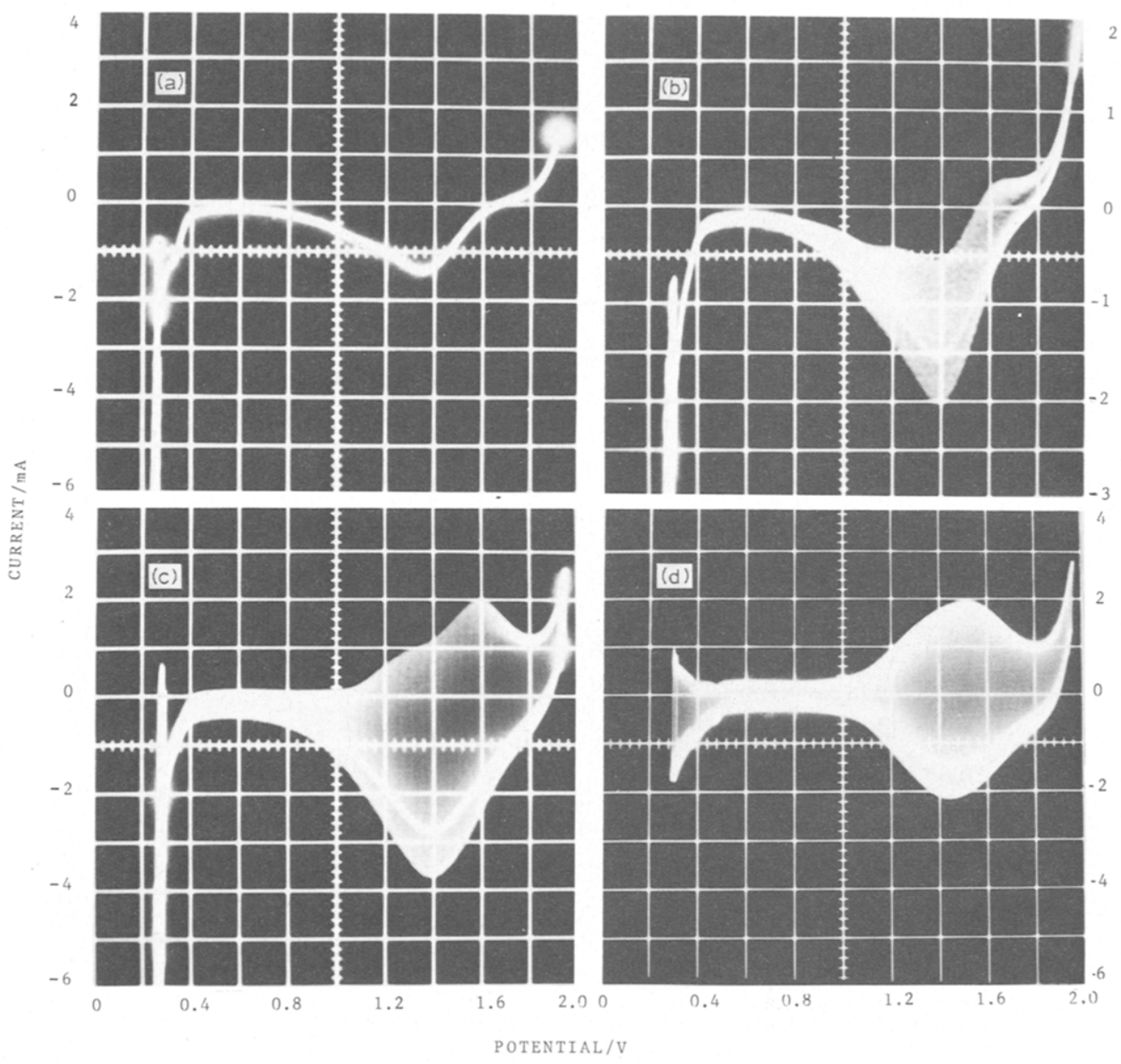

Fig. 6. (a) Single potential sweep voltammogram run from $E_{\mathrm{s}, \mathrm{a}}=2 \mathrm{~V}$ after holding the potential at $E_{\mathrm{s}, \mathrm{a}}=2 \mathrm{~V}$ for $5 \mathrm{~min} ; v_{\mathrm{g}}=2 \mathrm{~V} \mathrm{~s}^{-1} ; 1 \mathrm{MH}_{2} \mathrm{SO}_{4}$. (b) Single triangular modulated potential sweep voltammogram run from $E_{\mathrm{s}, \mathrm{a}}=2 \mathrm{~V}$ after holding the potential at $E_{\mathrm{s}, \mathrm{a}}=2 \mathrm{~V}$ for $5 \min ; v_{\mathrm{g}}=2 \mathrm{~V} \mathrm{~s}^{-1}$, $v_{\mathrm{m}}=10 \mathrm{~V} \mathrm{~s}^{-1}, A_{\mathrm{m}}=20 \mathrm{mV} ; 1 \mathrm{M} \mathrm{H}_{2} \mathrm{SO}_{4}$. (c) Single triangular modulated potential sweep voltammogram run from $E_{\mathrm{s}, \mathrm{a}}=2 \mathrm{~V}$ after holding the potential at $E_{\mathrm{s}, \mathrm{a}}=2 \mathrm{~V}$ for $5 \mathrm{~min} ; v_{\mathrm{g}}=2 \mathrm{~V} \mathrm{~s} \mathrm{~s}^{-1}, v_{\mathrm{m}}=100 \mathrm{~V} \mathrm{~s}^{-1}$, $A_{\mathrm{m}}=20 \mathrm{mV} ; 1 \mathrm{M} \mathrm{H}_{2} \mathrm{SO}_{4}$. (d) Single triangular modulated potential sweep voltammogram run from $E_{\mathrm{s}, \mathrm{a}}=2 \mathrm{~V}$ after holding the potential at $E_{\mathrm{s}, \mathrm{a}}=2 \mathrm{~V}$ for $5 \mathrm{~min} ; v_{\mathrm{g}}=0.1 \mathrm{~V} \mathrm{~s}^{-1}, v_{\mathrm{m}}=100 \mathrm{~V} \mathrm{~s}{ }^{-1}, A_{\mathrm{m}}=20$ $\mathrm{mV} ; 1 \mathrm{M} \mathrm{H} \mathrm{SO}_{4}$. 


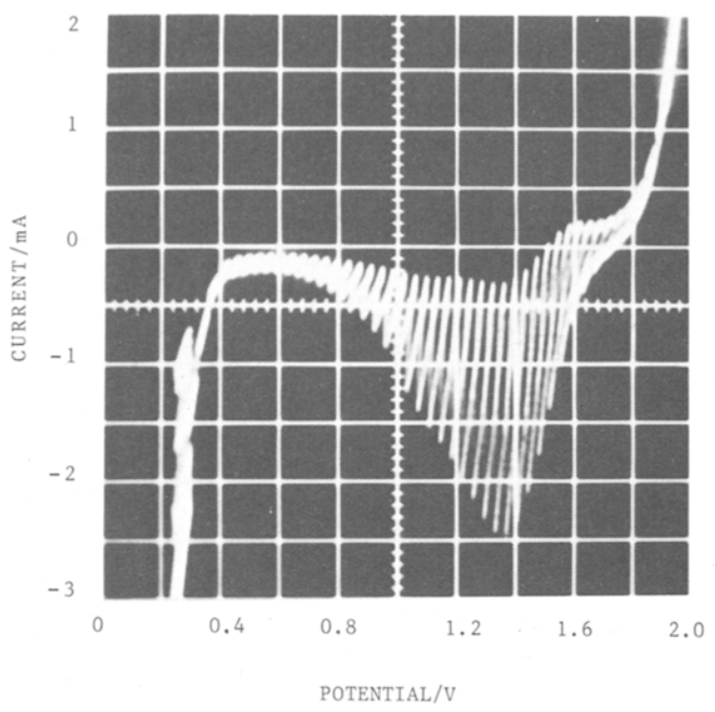

Fig. 7. Single triangular modulated potential sweep voltammogram run from $E_{\mathrm{s}, \mathrm{a}}=2 \mathrm{~V}$ after holding the potential at $E_{\mathrm{s}, \mathrm{a}}=2 \mathrm{~V}$ for $5 \mathrm{~min} ; v_{\mathrm{g}}=2 \mathrm{~V} \mathrm{~s}^{-1}, v_{\mathrm{m}}=5 \mathrm{~V} \mathrm{~s}^{-1}, A_{\mathrm{m}}=50 \mathrm{mV} ; 1 M \mathrm{H}_{2} \mathrm{SO}_{4}$.

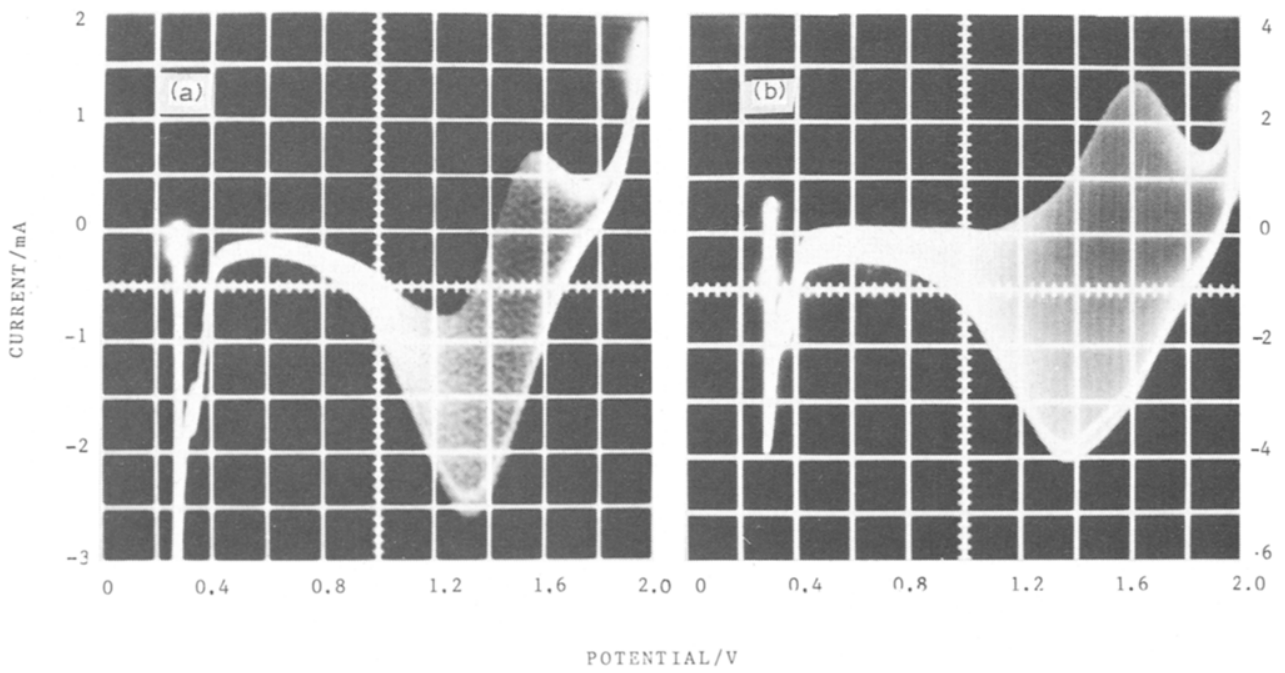

Fig. 8. (a) Single triangular modulated potential sweep voltammogram run from $E_{\mathrm{s}, \mathrm{a}}=2 \mathrm{~V}$ after holding the potential at $E_{\mathrm{s}, \mathrm{a}}=2 \mathrm{~V}$ for $5 \mathrm{~min} ; v_{\mathrm{g}}=2 \mathrm{~V} \mathrm{~s}^{-1}, v_{\mathrm{m}}=10 \mathrm{~V} \mathrm{~s}^{-1}, A_{\mathrm{m}}=20 \mathrm{mV} ; 1 M \mathrm{HClO}_{4}$. (b) Single triangular modulated potential sweep voltammogram run from $E_{\mathrm{s}, \mathrm{a}}=2 \mathrm{~V}$ after holding the potential at $E_{\mathrm{s}, \mathrm{a}}=2 \mathrm{~V}$ for $5 \mathrm{~min} ; v_{\mathrm{g}}=2 \mathrm{~V} \mathrm{~s}^{-1}, v_{\mathrm{m}}=100 \mathrm{~V} \mathrm{~s}^{-1}, A_{\mathrm{m}}=20 \mathrm{mV} ; 1 M \mathrm{HClO}_{4}$. 
Step (3) is followed by the ageing of $\operatorname{Pd}(\mathrm{O})^{*}$ represented by:

$\operatorname{Pd}(\mathrm{O})^{*}=\operatorname{Pd}(\mathrm{O})$

Reaction (4) should be related to a place exchange mechanism as already discussed for other noble metals in acid $[14,15]$.

On the basis of reactions (2)-(4) the average half-life time of the adsorbed $\mathrm{OH}$ on polycrystalline palladium can be estimated from the $Q_{\mathrm{a}}^{\mathrm{I}} / Q_{\mathrm{c}}^{\mathrm{I}}$ ratio vs. $f$ plot (Fig. 2). Thus, as a limiting case as $f$ approaches infinity, if only reaction (2) follows the potential perturbation, then the $Q_{\mathrm{a}}^{\mathrm{I}} / Q_{\mathrm{c}}^{\mathrm{I}}$ ratio tends to one. On the other hand, as $A_{\mathrm{m}} \rightarrow 0$ and $v_{\mathrm{m}} \rightarrow v_{\mathrm{g}}$, the voltammogram should approach the characteristics of the RTPS voltammogram of reactions (3) and (4). Likewise, when $Q_{\mathrm{a}}^{\mathrm{I}} / Q_{\mathrm{c}}^{\mathrm{I}}=2$, it means that the rate of reaction (3) in the anodic direction is equal to the rate of reaction (2) in the cathodic direction. Therefore, the $f$ value which determines $Q_{\mathrm{a}}^{\mathrm{I}} / Q_{\mathrm{c}}^{\mathrm{I}}=2\left(f^{*}\right)$, implies the fullfilment of the following average rate equations for step (2)

$v_{-2}=k_{-2} \theta_{\mathrm{PdOH}} c_{\mathrm{H}}+\exp [-(1-\beta) F E / R T]$

and for step (3)

$v_{3}=k_{3} \theta_{\mathrm{PdOH}} \exp \left[\beta^{\prime} F \dot{E} / R T\right]$

so that, at $f^{*}$

$v_{-2}=v_{3}$

where $c_{\mathrm{H}^{+}}$is the hydrogen ion concentration at the metal-solution interface, $\theta_{\mathrm{PdOH}}$ is the degree of surface coverage by $\mathrm{OH}$ species, and $\beta$ and $\beta^{\prime}$ are the symmetry factors of steps (2) and (3) for the corresponding anodic reactions which are assumed equal to 0.5 for each single step. The $f^{*}$ value for $Q_{\mathrm{a}}^{\mathrm{I}} / Q_{\mathrm{c}}^{\mathrm{I}}=2$ is $0.17 \mathrm{kHz}$ (Fig. 2). The average half-life time of adsorbed $\mathrm{OH}$ on polycrystalline palladium estimated from that figure is $6 \times 10^{-3} \mathrm{~s}$. From this value and eqns. (4)-(6), the value of $k_{3}$ is smaller than that of $k_{2}$ by the factor $\exp \left(F E_{1}^{\circ} / R T\right),\left(k_{3}\right)_{E_{1}^{\circ}} \simeq 3.6 \times 10^{-6} \mathrm{~A} \mathrm{~cm}^{-2}$.

The voltammetric response of another fast reaction (second electrochemical system) is detected in the $1.4-2.0 \mathrm{~V}$ range when the palladium electrode is polarized at potentials greater than $1.8 \mathrm{~V}$. This response, which correlates with the characteristics of the open circuit potential decay of the electrode polarized at $E_{\mathrm{s}, \mathrm{a}}$ (Fig. 5), is enhanced in the TMLPS voltammogram run from $E_{\mathrm{s} . \mathrm{a}}$ downwards, when the latter exceeds the oxygen evolution threshold potential (Fig. 4). The appearance of the second electrochemical system is accompanied by a change in colour of the electrode surface and a shift of the oxygen evolution voltammogram towards more positive potentials. Likewise, when the potential is held at $E_{\mathrm{s}, \mathrm{a}}$ for a certain time to thicken the anodic oxide layer, another more irreversible electrochemical process, probably involving the partial electrodissolution of the anodic oxide layer, takes place showing good correlation with previous results reported by Rand and Woods [16]. The voltammetric response of this faradaic process partially overlaps the response of the second electrochemical system and extends towards more negative potentials (Fig. 6). 
The second reversible system can be attributed to the formation of hydrous palladium oxides higher than $\mathrm{PdO}_{2}$. However, there is little information in the literature on the higher oxides of palladium as recently reviewed in ref. 17 . Thus, $\mathrm{PdO}_{3}$ was postulated as an intermediate in the OER [18,19] and the dubious possibility of the existence of a $\mathrm{PdO}_{2} / \mathrm{PdO}_{3}$ redox system was considered in the calculation of the potential-pH diagram of palladium [20]. The standard potential of the $\mathrm{PdO}_{2} / \mathrm{PdO}_{3}$ redox couple, as represented by the equilibrium:

$\mathrm{PdO}_{3}+2 \mathrm{H}^{+}+2 e^{-}=\mathrm{PdO}_{2}+2 \mathrm{H}_{2} \mathrm{O}$

is $E^{\circ}(\mathrm{NHE})=2.03 \mathrm{~V}[20]$. If one assigns the second electrochemical system located in the $1.2-1.8 \mathrm{~V}$ range to reaction (8) and the corresponding equilibrium potential estimated from the current peak potentials is $1.5 \mathrm{~V}$ (Fig. 4), one may conclude that during the OER, the anodic $\mathrm{PdO}_{2}$ layer growth is accompanied by $\mathrm{PdO}_{3}$ formation yielding a $\mathrm{PdO}_{2}$ anodic layer containing a small concentration of $\mathrm{PdO}_{3}$ species. This conclusion is coherent with previous data obtained with iridium and ruthenium electrodes in acid $[21,22]$ and with charge values and charge distributions resulting when either a potential holding at $E_{\mathrm{s}, \mathrm{a}}$ is including during the potential sweep or when it is not (Fig. 6). Furthermore, to admit the electroformation of $\mathrm{PdO}_{3}$ should be related to the formation of peroxide structures during sufficiently high anodic polarizations. It should also be considered that above $1.77 \mathrm{~V}$ the electrooxidation of water to $\mathrm{H}_{2} \mathrm{O}_{2}$ according to [20]

$2 \mathrm{H}_{2} \mathrm{O}=\mathrm{H}_{2} \mathrm{O}_{2}+2 \mathrm{H}^{+}+2 e^{-}$

$E^{\circ}(\mathrm{NHE})=1.77 \mathrm{~V}$, becomes thermodynamically possible and $\mathrm{H}_{2} \mathrm{O}_{2}$ formation at this potential has certainly been detected [23]. Reaction (9) can participate in the formation of peroxide structures. There is evidence that these types of structures are voltammetrically formed on other noble metals in acid electrolytes [24,25] and probably act as intermediates in the OER. Therefore, the composition of the anodic layer obtained after an anodic polarization in the OER potential range should consist of $\mathrm{PdO}$ and $\mathrm{PdO}_{2}$, as demonstrated for palladium electrodes anodized at 1.28 $\mathrm{V}$ [26], and small amounts of $\mathrm{PdO}_{3}$. The change of both the anodic layer composition, and the solution composition in contact with the electrode surface during the OER, explains the increase of anodic polarization in the voltammogram run from $E_{\mathrm{s}, \mathrm{a}}$ downwards as compared to that run from $E_{\mathrm{s}, \mathrm{c}}$ upwards. It is likely that the second electrochemical process found in the thick hydrous oxide layer potential range involves a relatively fast electron and proton transfer process as it was already postulated in a quasi-three dimensional ruthenium and iridium hydrous oxides structure [27].

In conclusion, the anodic processes occurring at sufficiently high anodic potentials can be represented in a more general way by admitting the formation of an anodic hydrous oxide layer $\mathrm{Pd}_{x} \mathrm{O}_{y} \cdot n \mathrm{H}_{2} \mathrm{O}$ whose stoichiometry changes according to the applied potential, so that $y \rightarrow 3 x$ as a limiting case as the potential increases.

Furthermore, at potentials in the OER potential range, $\mathrm{PdO}_{2}$ is partially electrochemically transformed into $\mathrm{PdO}_{3}$, probably involving some peroxidic structure which becomes a reaction intermediate in the OER. 


\section{ACKNOWLEDGEMENT}

INIFTA is sponsored by the Universidad Nacional de La Plata, the Consejo Nacional de Investigaciones Científicas y Técnicas and the Comisión de Investigaciones Científicas (Provincia de Buenos Aires).

\section{REFERENCES}

1 B.E. Conway, H. Angerstein-Kozlowska, F.C. Ho, B. MacDougall and S. Gottesfeld, Faraday Discuss. Chem. Soc., 56 (1973) 210.

2 N.R. de Tacconi, J.O. Zerbino and A.J. Arvia, J. Electroanal. Chem., 79 (1977) 287.

3 C.M. Ferro, A.J. Calandra and A.J. Arvia, J. Electroanal. Chem., 59 (1975) 239.

4 J.O. Zerbino, N.R. de Tacconi, A.J. Calandra and A.J. Arvia, J. Electrochem. Soc., 124 (1977) 475.

5 J.O. Zerbino, J.R. Vilche and A.J. Arvia, J. Appl. Electrochem., 11 (1981) 703.

6 E. Santos and M.C. Giordano, J. Electroanal. Chem., 172 (1984) 201.

7 S. Bilmes, N.R. de Tacconi and A.J. Arvia, in preparation.

8 T. Schober, V. Sorajic and A. Meisenberg, Metallography, 8 (1975) 359.

9 B.E. Conway, H. Angerstein-Kozlowska, W.B.A. Sharp and E.E. Criddle, Anal. Chem., 45 (1973) 1331.

10 K. Gossner and E. Mizera, J. Electroanal. Chem., 125 (1981) 347.

11 A.E. Bolzán, M.E. Martins and A.J. Arvia, J. Electroanal. Chem., 157 (1983) 339.

12 A.E. Bolzán, M.E. Martins and A.J. Arvia, J. Electroanal. Chem., 172 (1984) 221.

13 C. Pallotta, N.R. de Tacconi and A.J. Arvia, Electrochim. Acta, 26 (1981) 261.

14 H. Angerstein-Kozlowska, B.E. Conway and B.A. Sharp, J. Electroanal. Chem., 43 (1973) 9.

15 M.E. Folquer, J.O. Zerbino, N.R. de Tacconi and A.J. Arvia, J. Electrochem. Soc., 126 (1979) 592.

16 D.A.J. Rands and R.Woods, J. Electroanal. Chem., 31 (1971) 29.

17 J. Genesca and L. Victori, Rev. Coat. Corros., 4 (1981) 325.

18 F. Jirsa. Z. Phys. Chem,, 113 (1924) 241.

19 A.C.C. Tseung and S. Jasen, Electrochim. Acta, 22 (1977) 31.

20 M. Pourbaix, Atlas of Electrochemical Equilibria in Aqueous Solutions, Pergamon Press, New York, 1966.

21 D.N. Buckley and L.D. Burke, J. Chem. Soc. Faraday Trans I. 72 (1976) 2431.

22 L.D. Burke, O.J. Murphy, J.F. O'Neill and S. Venkatesan, J. Chem. Soc. Faraday Trans. I, 73 (1977) 1659.

23 J.P. Hoare, J. Electrochem. Soc., 111 (1964) 610.

24 M.I. Florit, M.E. Martins and A.J. Arvia. J. Electroanal. Chem., 126 (1981) 255.

25 C. Pallotta, N.R. de Tacconi and A.J. Arvia in W.E. O'Grady, P.N. Ross, Jr., and F.G. Will (eds.), Proc. Symp. Electrocatalysis, Vol. 82-2, 1982, p. 92.

26 K.S. Kim. F. Gossmann and N. Winograd, Anal. Chem., 46 (1974) 197.

27 L.D. Burke and E.J.M. O'Sullivan, J. Electroanal. Chem., 117 (1981) 155. 